\title{
Forestry and Life Cycle Assessment
}

\author{
Andreja Bosner, Tomislav Poršinsky and Igor Stankić \\ Faculty of Forestry, University of Zagreb \\ Croatia
}

\section{Introduction}

Ever since recognizing the effect of global warming and ozone degradation, scientists are trying to develop new methods of environmental impact assessment to ensure environmental protection. Life Cycle Assessment (LCA) is such a method and with its fully comprehensive approach better nature conservation is possible. Sustainability can be achieved through minimal consumption of renewable and non-renewable materials, energy saving, reuse and recycling, emission control, etc. However, the cost aspect is still the most important factor in today's world and therefore achieving sustainability is made even more difficult. LCA according to FAO is a useful tool for comparing the environmental aspects of specific products as it enables the ecological comparison of two or more products made of different raw materials but used for the same purpose. LCA can help in measuring environmental aspects and potential impacts of a product through its entire life-cycle from raw material acquisition (as the beginning of the life-cycle) to manufacturing, use, recycling, reuse and final disposal (as the end of the product's life-cycle). The ISO/EN 14040 defines LCA as a technique for assessing the environmental aspects and potential impacts associated with a product by: 1) compiling an inventory of relevant inputs and outputs of a system; 2) evaluating potential environmental impacts associated with those inputs and outputs; 3) interpreting the results of the inventory analyses and 4) impact assessment in relation to the objectives of the study (Figure 1).

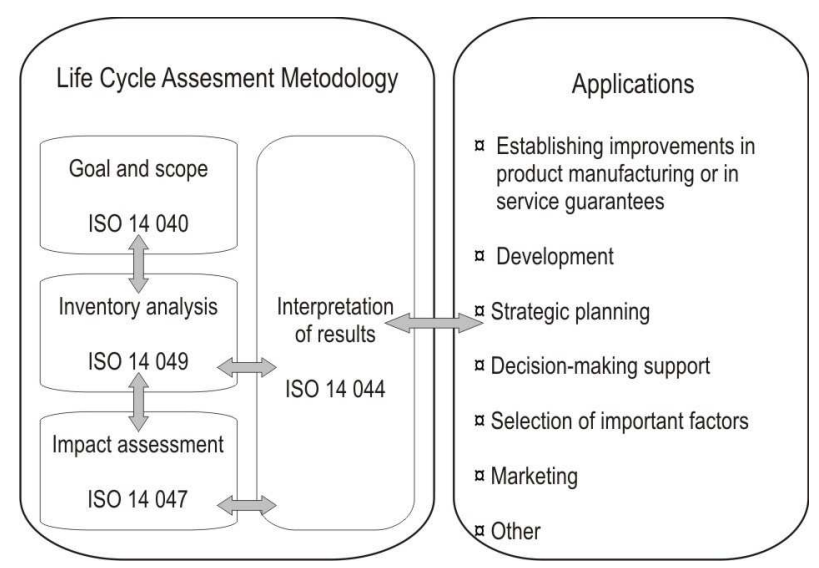

Fig. 1. Phases in the LCA according to ISO standards (source: www.iso.org) 
Goal and scope of the LCA explain why the study is being done, set functional units (for example $1 \mathrm{~m}^{3}$ or $1 \mathrm{~m}^{2}$ or 1 tonne are usually taken for wood products) and give system boundaries to determine which unit-processes of LCA will be considered in the study (data quality requirement, precision and representatives of data). Inventory analysis indicates relevant input data (used energy, raw and supporting materials etc.) and output data (releases to air, water, land and manufacture of side products, by-products etc.). To avoid high complexity of the inventory analysis, processing machines, manpower, buildings and land-use for biological production or transportation are not included. Impact assessment reveals the potential environmental repercussions and their significance. Impact categories can be defined form local to global. Interpretation of results combines all the findings together and final conclusions and recommendations can be made.

Other ISO/EN standards deal with LCA as well:

- ISO 14020: 2000 (Environmental labels and declarations - General principles)

- ISO 14021: 1999 (Environmental labels and declarations - Self-declared environmental claims, Type II environmental labelling)

- ISO 14024: 1999 (Environmental labels and declarations - Type I environmental labelling - Principles and procedures)

- ISO 14025: 2006 (Environmental labels and declarations - Type III environmental declarations - Principles and procedures)

- $\quad$ ISO 14040: 2006 (Environmental management - Life cycle assessment - Principles and framework)

- $\quad$ ISO 14044: 2006 (Environmental management - Life cycle assessment - Requirements and guidelines)

- ISO/TR 14047: 2003 (Environmental management - Life cycle impact assessment Examples of application of ISO 14042)

- ISO/TS 14048: 2002 (Environmental management - Life cycle assessment - Data documentation format)

- ISO/TR 14049: 2000 (Environmental management - Life cycle assessment - Examples of application of ISO 14041 to goal and scope definition and inventory analysis).

According to COST ACTION E9 Memorandum of Understanding (Life cycle assessment of forestry and forest products) Europe currently produces and consumes the roundwood equivalent of 400 million $\mathrm{m}^{3}$ of wood products. Forests, moreover cover more than $25 \%$ of the world's land area with approximately 600 billion $\mathrm{m}^{3}$ of standing stock. Annually 3.6 billion $\mathrm{m}^{3}$ of wood is used as firewood $(55 \%)$ or as different products $(45 \%)$. Because wood is a renewable energy source, $\mathrm{CO}_{2}$ neutral and recyclable, it represents the most important renewable raw material and fuel and a very important carbon sink. Even more importantly, wood can be permanently available if sustainable forest management is made obligatory. The main reasons of performing LCAs by COST Action E9 of forestry and forest products are:

- To enable comparison between different materials, provided that products are used for the same purpose;

- To obtain quantified and reliable information of benefits of wood products and their environmental impact, so that industry and policy makers can use such information;

- To highlight unknown or uncertain areas of environmental impact of wood products; 
- To improve production and recycling techniques by minimizing steps of high environmental impacts or choosing different processing routes to reduce such high environmental impact.

However, certain problems when dealing with LCA in forestry arise:

- $\quad$ Forestry uses considerable areas of land;

- Life cycle of forest products can vary from relatively short (for example paper) to very long (for example structural timber);

- Long production chains which start in the forest and end with disposal or burning for energy;

- Forest products have complex relationships between products, by-products and waste.

Complexity of the LCA study is shown in figure 2.

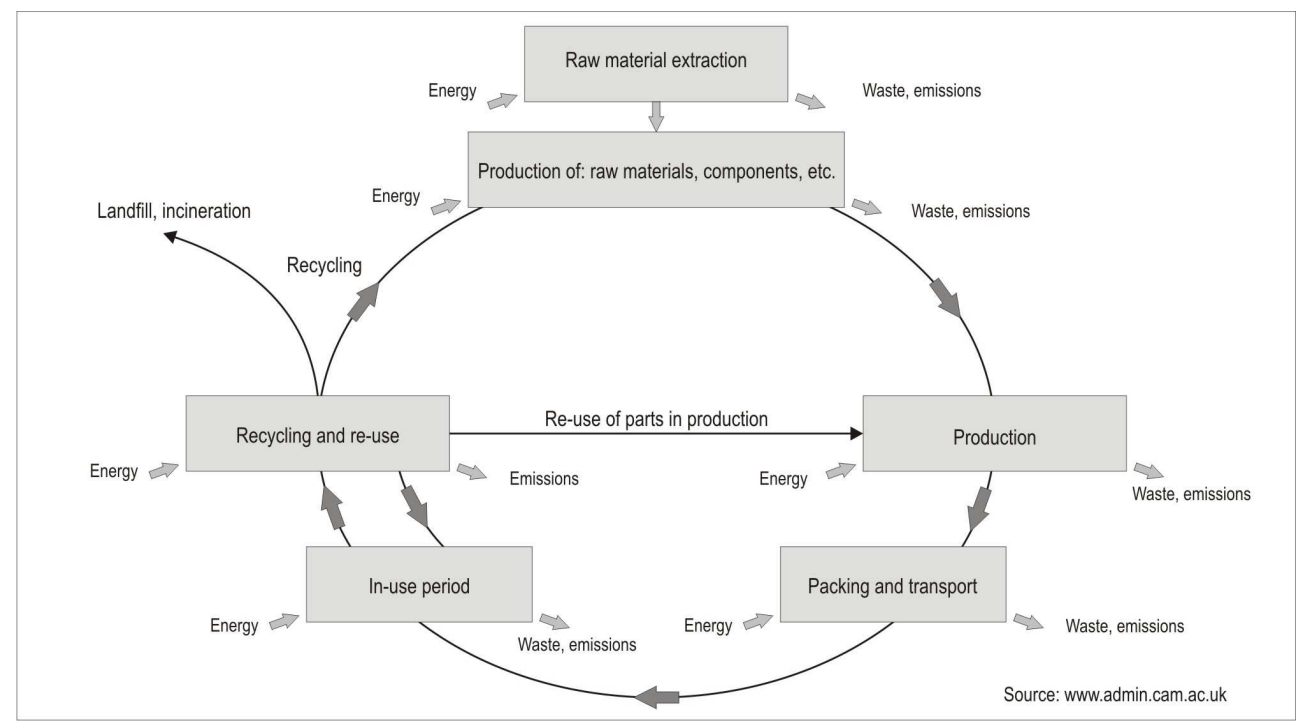

Fig. 2. Product lifetime

\section{Challenges for LCA in forestry}

The carbon cycle starts with the biosynthesis in the forest and ends by releasing $\mathrm{CO}_{2}$ into the atmosphere during combustion or biodegradation. The most important material and energy cycles of wood as a renewable raw material should be therefore considered in LCA studies. Production of timber requires large area of land, but different kinds of land use should be also considered and compared, for example timber production in forests in comparison to agriculture raw material production, renewable forest material and fuel production in comparison to the exploitation of non-renewable materials and fuels and of land use in industry. Different forest management systems should also be compared and studied. Complexity of LCA studies for forestry and relating industries is shown in Figure 3 by Jungmeier (2003) in his System analysis of forestry, forest products and recovered wood (COST Action E9 and E31). 


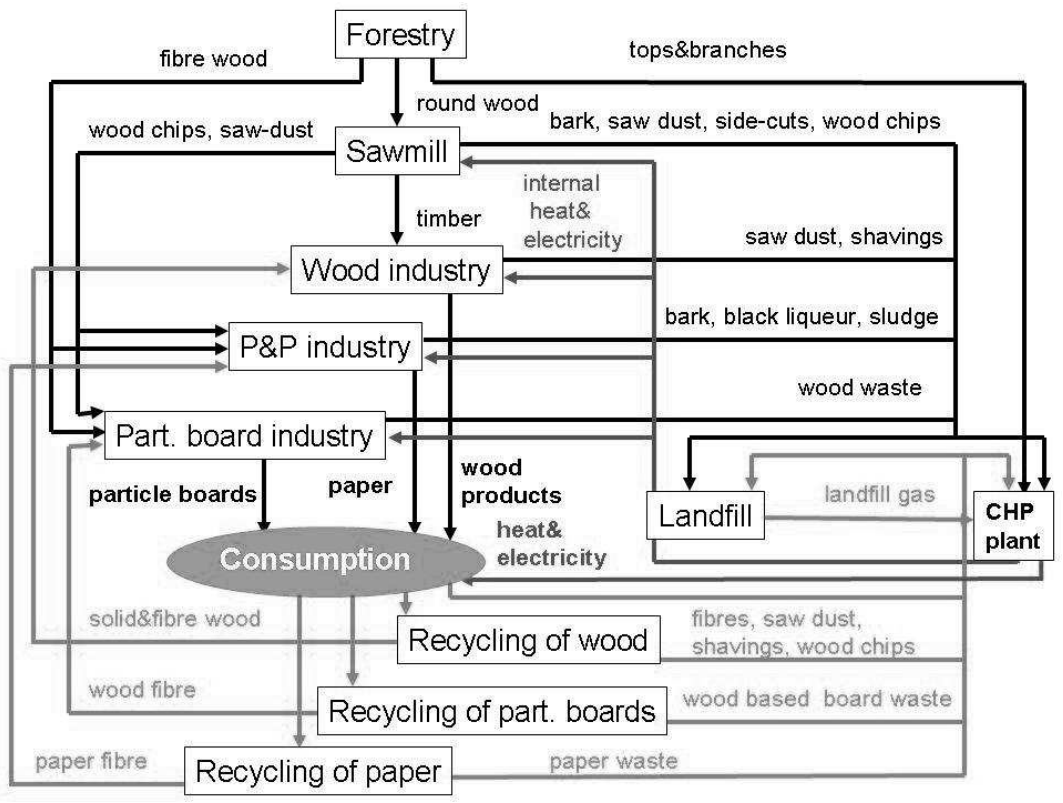

Fig. 3. Complexity of forestry products by Jungmeier (2003)

\subsection{Space-time aspect}

Many scientists believe that time effect should be excluded from LCA studies. However, in forestry social and time aspects are important, not just because forests affect on soil stability, water quality, biodiversity, wildlife habitat, but also because of the most important carbon cycle. Frühwald (1995) emphasises that forests are a part of the environment and therefore should be considered as an impact category of its own. Furthermore, forests are a substantial part of the global ecosystem and are negatively influenced not only by poor or inadequate management, but also by polluted air, acid rain etc. LCA is a method mainly focused on industrial production and to include/expand it to wood production and make it possible for forestry it should consider land use (biological production) and site conditions of raw material production. Only a serious impact assessment can characterize a substance as an environmental burden. If the emissions of a substance (such as $\mathrm{CO}_{2}$ ) is interpreted as a burden, consequently a reduction of this environmental burden by fixing this substance in the biological growth process should be stated in the inventory and should be interpreted as a benefit (Thoroe and Schweinle, 1995).

Even though in industrial production it is sufficient to concentrate on flows between different phases of a product lifetime, in forestry that is insufficient and stocks should also be considered. To make this possible, raw material acquisition i.e. forest production should be standardized. Standard argument for exclusion of beneficial effects forests have on the environment is a lack of methods for measuring such effects (Thoroe and Schweinle, 1995).

To understand and quantify the role of the forest ecosystem in the carbon cycle it is

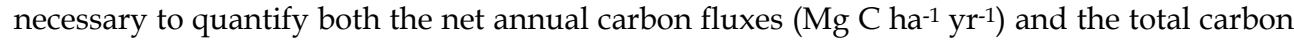


content (Mg C ha-1) of representative forest ecosystems, thereby including the carbon fluxes and stocks in the soil (Nabuurus and Mohren, 1993). Virtanen and Nilsson (1993) made a life cycle analysis of waste paper recycling, where $\mathrm{CO}_{2}$ fixation was 0.7 to $0.9 \mathrm{~kg}$ for each $\mathrm{kg}$ of biomass (logs including bark and water content). Calculations of net $\mathrm{CO}_{2}$ uptake for $1 \mathrm{~kg}$ of biomass were $0.46 \mathrm{~kg} \mathrm{CO}$-equivalents, which gave $0.92 \mathrm{~kg} \mathrm{CO}$-equivalents per kilo of usable wood (assuming 50\% of water content). Grasser (1994) makes $\mathrm{CO}_{2}$ uptake calculations in a stack-wood chain. The chain stars with wood formation, and the $\mathrm{CO}_{2}$ uptake is based on a carbon content of $0.5 \mathrm{~kg}$ per kilo of oven dry matter, which means 1.833 $\mathrm{kg}$ of $\mathrm{CO}_{2}$ uptake per kilo of usable wood (including bark). To provide a kilo of usable wood (including bark), $1.2 \mathrm{~kg}$ of wood needs to be cut, of which $0.2 \mathrm{~kg}$ will stay in the forest as wood waste and decay and the bounded $\mathrm{CO}_{2}$ within will be set free again during its biological decomposition. This represents $17 \%$ of the total growth. Lox (1994) calculates $\mathrm{CO}_{2}$ uptake of produced cardboards and states that biological decomposition of wood waste if different. $34 \%$ of the total growth will stay in forest, which means $0.5 \mathrm{~kg}$ of wood waste per kilo of usable wood (including bark) because only cellulose and hemi cellulose fraction will decompose, which means $2.2 \mathrm{~kg}$ of $\mathrm{CO}_{2}$ uptake per kilo of usable wood. Different ways to calculate the $\mathrm{CO}_{2}$ uptakes have been mentioned and De Feyter (1995) states that the $\mathrm{CO}_{2}$ should not be seen as a credit, but as an implementation of the carbon neutrality of wood when looking at its lifecycle. The emitted carbon can be present in the form of $\mathrm{CO}_{2}, \mathrm{CO}, \mathrm{CH}_{4}$ etc. and those emissions have a different behaviour towards environmental effects which can result in different $\mathrm{CO}_{2}$-equivalents.

When comparing recycling and non-recycling of paper in LCA, most analysis show a higher contribution to global warming of recycling systems. This is because recycling systems use more fossil fuels, however recycling of paper holds carbon longer in fixed rotation, but this aspect cannot be taken into account in LCA because LCA still has a static approach and no time aspects.

Wollenman (2006) investigates aims at balancing carbon sequestration and emission fluxes of forest land use to evaluate methodology for a close-to-nature and plantation regime. The regimes have a positive sequestration capacity of about $85 \mathrm{~kg} \mathrm{C} \mathrm{m}^{3}$ (eucalyptus plantation) and about $180 \mathrm{~kg} \mathrm{C} \mathrm{m}^{3}$ (close-to-nature beech forest) respectively. Assuming a given area of forest cover a division of so called ecological labour between plantation forest and forest reserve provides a net carbon sink capacity of $0.18 \mathrm{~kg} \mathrm{C} \mathrm{m}^{-2} \mathrm{a}^{-1}$ compared to $0.14 \mathrm{~kg} \mathrm{C} \mathrm{m}^{-2} \mathrm{a}^{-1}$ for closeto-nature regime. These results clearly indicate that management regime determines the net carbon sink capacity and that so called ecological labour division between intensively and unmanaged forests offer opportunities to maximize carbon sequestration.

Forest roads provide accessibility to forests, and their construction is one of the largest investments in forestry itself. Multi-purpose use of forest roads creates problems involving the process of building and maintaining forest roads in the life cycle assessment of forest products. Lifetime of roads is difficult to define, since it depends on many factors and generalizes their depreciation over time. Mroueh et al (2000) in a study of life cycle assessment of road construction analyze numerous factors (environmental loadings, Table 1) that need attention:

- Consumption of energy and fuels (including energy consumed by the machine, or the vehicle during the processing of raw materials and energy contained in organic materials); $\mathrm{E}$ 
- Emissions and dust;

- Environmental noise pollution (Table 2);

- Substances released into the soil depending on the type of building material (for example sulphate compounds, mercury, arsenic, chromium, copper, vanadium, etc.).

\begin{tabular}{|c|c|c|}
\hline Impact category & Environmental loading & Results, unit \\
\hline \multirow{5}{*}{ Resource use } & Use of natural resources & t/construction selected ${ }^{*}$ \\
\hline & Industrial by products & $\mathrm{t} /$ construction selected $^{*}$ \\
\hline & Energy & $\mathrm{kWh} /$ construction \\
\hline & Fuels $^{* *}$ & $\mathrm{~m}^{3} /$ construction \\
\hline & Land use & $\begin{array}{l}\text { Verbal estimation of the } \\
\text { significance of land use }\end{array}$ \\
\hline \multirow{3}{*}{$\begin{array}{l}\text { Effluents to soil } \\
\text { and waters }\end{array}$} & $\begin{array}{l}\text { Leaching of metals (e.g. As, Cd, Cr, } \\
\mathrm{Cu}, \mathrm{Mo}, \mathrm{Ni}, \mathrm{Se}, \mathrm{Pb}, \mathrm{Zn})\end{array}$ & $\mathrm{mg} / \mathrm{m}^{2}$ of construction selected \\
\hline & $\begin{array}{l}\text { Leaching or migration of compounds } \\
\text { from materials }\end{array}$ & $\mathrm{mg} / \mathrm{m}^{2}$ of construction selected \\
\hline & $\mathrm{CI}, \mathrm{SO}_{4}{ }^{* * *}$ & $\mathrm{mg} / \mathrm{m}^{2}$ of construction selected \\
\hline \multirow{6}{*}{ Emissions to air } & $\mathrm{CO}_{2}$ & \multirow{6}{*}{$\mathrm{kg} /$ construction selected } \\
\hline & $\mathrm{NO} x$ & \\
\hline & $\mathrm{SO}_{2}$ & \\
\hline & VOC & \\
\hline & $\mathrm{CO}$ & \\
\hline & Particles & \\
\hline Wastes & Inert waste & $\mathrm{t} / \mathrm{km}$ \\
\hline Other loadings & Noise & Noise $\mathrm{x}$ time $/ \mathrm{km}$ \\
\hline
\end{tabular}

*Only constructions that meet the same performance requirements and are designed for the same site are compared in the assessment.

"Fuel means diesel oil used to power machines and vehicles or oil used as a raw material in industry.

Can be presented separately or included in the energy consumption.

** The substance included in the analysis is selected according to the material used.

Table 1. Environmental loadings in the life cycle assessment of road construction

The same authors according to the study of Häkinnen and Mäkelä (1996) estimate the environmental burdens that arise during maintenance and repair of roads in Finland during the period of 50 years. The frequency of repairs is determined in advance adopted strategy (Table 3).

Water-soluble substances present in the materials can be carried away by run-off water into the environment and into the groundwater. The amount of leaching depends on the composition of the material, the amount of water passing through material and the manner in which it is laid (Ranta et al. 1987). Pollutants leaching out of alternative constructions over a hundred years are presented in table 4 (Mroueh et al., 2000).

Some of the most important factors, such as COD emissions to water and land, have been absent from this study and applicable calculation methods requires more extensive further research. The creation of procedures for calculating the environmental loadings would be important for assessing the impacts of material selections and the total loadings of road usage. 


\begin{tabular}{|l|c|c|}
\hline \multirow{2}{*}{ Machine type } & $\begin{array}{c}\text { Noise } \\
\text { level } \\
\text { range }\end{array}$ & $\begin{array}{c}\text { Average } \\
\text { noise level }\end{array}$ \\
\cline { 2 - 3 } & \multicolumn{2}{|c|}{ dBA } \\
\hline Drilling rig & $98-101$ & 100 \\
\hline Blasting & $125-136$ & 130 \\
\hline Hydraulic hammer & $87-92$ & 90 \\
\hline Conveyor belt & 84 & 84 \\
\hline Crushing plant & 100 & 100 \\
\hline Hydraulic excavator & $82-100$ & 89 \\
\hline Earth moving machines & 91 & 91 \\
\hline Lorry & 84 & 84 \\
\hline Bulldozer & $80-89$ & 84 \\
\hline Road roller & $84-101$ & 92 \\
\hline Asphalt layer & $74-89$ & 81 \\
\hline Road grader & $85-89$ & 87 \\
\hline
\end{tabular}

*At a distance of $7 \mathrm{~m}$ from the source

Table 2. Noise levels of working machines* (Mroueh et al. 2000)

\begin{tabular}{|l|c|c|}
\hline \multicolumn{1}{|c|}{ Environmental loadings } & Construction & Maintenance \\
\hline $\mathrm{CO}_{2}, \mathrm{~kg} / \mathrm{km}$ & $263000-562000$ & 33900 \\
\hline $\mathrm{SO}_{2,} \mathrm{~kg} / \mathrm{km}$ & $280-610$ & 4,1 \\
\hline $\mathrm{NO}, \mathrm{kg} / \mathrm{km}$ & $2600-3800$ & 140 \\
\hline $\mathrm{CO}, \mathrm{kg} / \mathrm{km}$ & $600-1100$ & 20 \\
\hline Violatile organic compounds (VOC), $\mathrm{kg} / \mathrm{km}$ & $550-980$ & 210 \\
\hline Fuel consumption, $1 / \mathrm{km}$ & $63000-100000$ & 18200 \\
\hline Energy consumption, $\mathrm{kWh} / \mathrm{km}$ & $790000-1.470000$ & 183300 \\
\hline
\end{tabular}

Table 3. Environmental loadings caused by road construction and maintenance (Mroueh et al. 2000)

The classic LCA includes a static approach that ignores the dimension of time and flows are determined through emissions that occur in a certain production period, while the duration of the period is not taken into account. Forestry on the other hand just by using dynamic models predicts the production and thus the time dimension is completely necessary for modelling. Furthermore, the accumulation of substances in the classical analysis of life cycles are ignored and only the flows of goods between production systems and the environment are taken into account, while in forestry supplies represent the basic information for modelling. It should be noted that the static analysis of the life cycle for 
forestry has not yet been performed because of the mentioned dynamic character of the forestry production systems in general. Karjalainen et al (2001) reported that in the short term analysis it is easier to implement dynamic models in the study of forestry especially in view of the circulation of substances $\left(\mathrm{CO}_{2}, \mathrm{NH}_{3}, \mathrm{NO}_{3}\right.$, etc.).

\begin{tabular}{|l|c|c|c|c|c|}
\hline \multirow{2}{*}{ Substance } & Ash FA1 & Ash FA2/FA3 & Concrete CC1 & Concrete CC2 & B-F slag BFS \\
\cline { 2 - 6 } & \multicolumn{5}{|c|}{$\mathrm{mg} / \mathrm{m}^{2}$} \\
\hline Sulphate & 692000 & 446000 & 546000 & 791000 & - \\
\hline Chloride & 84600 & 44600 & 13800 & 20800 & - \\
\hline Arsenic & 84 & 69 & - & - & $<0.1$ \\
\hline Barium & 7.7 & 7.7 & - & - & - \\
\hline Cadmium & 0.06 & 0.05 & - & - & 0.4 \\
\hline Chrome & 250 & 140 & 92 & 131 & $<0.1$ \\
\hline Copper & 4.4 & 2.7 & 51 & 65 & $<1$ \\
\hline Mercury & 0.3 & 0.2 & - & - & - \\
\hline Molybdenum & 1260 & 1260 & - & - & $<0.1$ \\
\hline Nickel & 19 & 12 & - & - & $<0.1$ \\
\hline Lead & 0.15 & 0.15 & - & - & 4 \\
\hline Selenium & 45 & 28 & - & - & - \\
\hline Vanadium & 615 & 615 & - & - & 5 \\
\hline Zinc & 3 & 2 & - & - & $<10$ \\
\hline
\end{tabular}

Table 4. Pollutants leaching out over hundred years

Domino effect caused by land use begins with the influence of vegetation on the soil and ground, the influence of the nutrients and water in the soil, soil compaction (the probability of erosion, and thus the loss of fertile soil), until the end of the product life cycle, through which one can see the total impact of products on the environment (Guinée et al 2006).

Cowell and Clift (2000) proposed how to solve the problem of soil erosion in the life cycle assessment. They believe that soil washout is a category of impact, the consequence is the erosion of fertile soil $(\mathrm{kg} / \mathrm{ha} / \mathrm{yr})$, and indication of the erosion is presented with global supplies of fertile soil. Global supplies of fertile soil are determined as the ratio of total upper layer of soil in the world (tonnes) and of an annual loss of the upper layers of soil due to erosion $(\mathrm{t} / \mathrm{yr})$.

\subsection{Forest products}

The definition of waste in the context of life cycle analysis is given in the standard ISO 14040 ("output from the production process that no longer can be used"), but in forestry waste can get a new meaning. A typical example of waste transferring to product in forestry is in the extraction of forest residue for energy purposes (branches and tree tops for example which are a by-product of wood in the timber assortment production, and usually represent waste in wood cuttings). In case the forest residue is left to decompose in the forest, i.e. additional profit will not be made; it represents a loss or a waste.

As well as the term "waste" is more complex when dealing with forestry, complications arise in use of other terms for products. A group of standards, ISO 14000, gives definitions for a 
main product (a product or a co-product which depends on economics and on the conversion of production process itself), a final product (product which requires no additional transformations prior to its use), a by-product (the product is not the intended output of a process and there is a market for the product; economic value is relatively low), a co-product (any of two or more products from the same unit process; production of this product is the intended output of the process with a defined market and economic value is relatively high) and a waste (any output from the production system which is disposed of and will not go further processing). It is clearly defined that a product is a physical things with measurable characteristics such as size, colour, taste, etc., resulting in the production process or services offered to consumers and requested by the consumer. Definitions of other sub-products depend entirely on the current market conditions. In wood processing many "waste streams" are used for internal heat or energy, which can also cause problems in the allocation procedure and definition of system boundaries. Wood itself, as an output, can be referred to as "kg absolute dry" or in "kg with X\% moisture content dry base" (Karjalainen et al., 2001).

Apart from wood products there are many other products which can be gained from the forest and also have market value. Up till 2001 and COST E9 2001 workshop (Energy, carbon and other material flows in the life cycle assessment of forestry and forest products) the nonwood products have not been mentioned in the LCAs on wood products and no environmental impacts have as yet been allocated. Compared to the mass of wood produced and harvested in the forests, the amount of non-wood products is generally bellow $1 \%$ (Schwaiger and Zimmer, 2001). Schwaiger and Zimmer (2001) made a survey of reported non-wood products in tonnes per year according to the national data-bases and UNECE/FAO study (Table 5).

\begin{tabular}{|c|c|c|c|c|c|c|c|c|}
\hline \multirow[t]{2}{*}{ State } & Resin & Mushrooms & $\begin{array}{c}\text { Game and } \\
\text { other hunted } \\
\text { animals }\end{array}$ & Berries & $\begin{array}{l}\text { Reindeer } \\
\text { (Rangifer } \\
\text { tarandus) }\end{array}$ & Cork & Chestnuts & Others \\
\hline & \multicolumn{8}{|c|}{$t / y r$} \\
\hline Austria & - & - & - & - & - & - & - & - \\
\hline Denmark & - & - & - & - & - & - & - & - \\
\hline Finland & - & 1408 & 5857 & 8441 & 2200 & - & - & $311^{*}$ \\
\hline France & - & 8200 & - & 1000 & - & 4000 & - & 600 \\
\hline Germany & - & - & - & - & - & - & - & - \\
\hline Greece & 6140 & - & - & - & - & - & - & - \\
\hline Ireland & - & - & - & - & - & - & - & - \\
\hline Italy & - & 2614 & - & 496 & - & 9204 & 69852 & 22658 \\
\hline Norway & - & 1200 & 7787 & 25000 & - & - & - & 1500 \\
\hline Slovenia & - & 800 & 840 & 600 & - & - & - & 3000 \\
\hline Sweden & - & 8500 & 17000 & 20700 & - & - & - & 26163 \\
\hline Switzerland & - & 735 & 1597 & - & - & - & - & 525 \\
\hline
\end{tabular}

*Finland uses 30.1 million $\mathrm{m}^{3}$ of peat for energy and 1.6 million $\mathrm{m}^{3}$ for horticultural and bedding peat out of forests.

Table 5. Reported non-wood products in tonne per year. 
It is obvious that many data is not available.

\subsection{Data availability}

Life cycle analysis has a static character, which represents a problem of applicability in forestry, because forestry is determined by works in space and time and thus has a dynamic character. There is a big difference between the duration and physical activity between the chain cycles of industrial products and production chains in forestry so there is a the need to develop a modelling approach that will enable the creation and collection of representative data for the accurate analysis.

The modelling can use these types of data (Karjalainen et al., 2001).:

- Empirical models - modelling is based on an analysis of existing data. Inventory based modelling is based on knowledge of the past and present situation.

- Process based models - development modelling with prediction of future events, taking into account any changes in the production process. Nonlinear effects can be taken into consideration by using corresponding productivity models or other process models.

- Hybrid models

For modelling it is essential that complex dynamic models are simplified in an appropriate way and as such are used in the analysis of the life cycle. Depending on forest management authors propose the rotation (management) period to be determined in two ways:

- For even aged forests a modelled period (determined by the length of rotations) is proposed;

- For selection forests it is proposed to use a period of 120 years.

Berg (1998) presented how different ways of data collection can give considerable differences in results, which may or may not be dependent on physical factors. Data were produced from two kinds of sources:

1. Statistics regarding actual work volume (area in hectares, cubic meters of harvested timber or tonne per kilometre of made wood transport).

2. Operational data or work study data about production efficiency and fuel consumption per work or time unit.

Another approach was also tried and data were collected from vast forest area during oneyear work operations. Records were kept of all recourses allotted to that area in order to deliver the timber that was transported from the area. During collection, data was sorted according to four origins:

1. Measurements of actual consumption of fossil fuel and actual delivery of timber.

2. Measurements and constants (for example actual wood volume produced with actual machine hours, but with a measured constant of fuel/machine hour).

3. Local averages of data concerning equipment of the specific area.

4. General averages

Author claims that discrepancies occurred due to several reasons. Gross data did not cover all the measurements performed, problems occurred between boundary operations and 
secondary transport, logging and stand treatment appeared and there was different data quality depending on data origin. Data from contractors were seldom available or not certified according to ISO standards. Available emission factors in literature were not appropriate with respect to fuels and engines used.

Berg and Karjalainen (2000) revealed the importance to depend on the origin and quality of data. In their study which was based on data of environmental loads from forest operations in Sweden and Finland in the late 1980s and early 1990s, the authors have compared records of $\mathrm{CO}_{2}$ emissions from logging operations, transport of timber to industry and some silvicultural activities. Even though harvested volumes in both countries were similar, together with operational conditions (terrain difficulty and level of mechanization in thinnings were the only differences) and machine types used in logging, mixed origin of data caused mistakes in calculating energy consumption. Two types of data were available, either from time-studies or data from follow-up routines.

Athanassiadis (2000) reported of difficulty to get specific data from the industry due to confidentiality problems. Author in his study summarizes the results from four separate studies on energy and resource consumption and emissions during the life cycle phases of harvesters and forwarders in the cut-to-length harvesting systems. Energy input during operations was $82 \mathrm{MJ} / \mathrm{m}^{3}, 11 \%$ was due to energy consumption during the production phase of the fuel. Exhaust emissions varied considerably depending on the kind of fuel that was examined (rapeseed methyl ester, environmental class 1 and environmental class 3 diesel fuels) and on whether emissions produced during the production phase of the fuels were taken onto consideration. It was also estimated that $35 \mathrm{l} / 1000 \mathrm{~m}^{3}$ of chainsaw oil was used for felling and crosscutting while hydraulic oil spillage from both harvesters and forwarders was $201 / 1000 \mathrm{~m}^{3}$. $52 \%$ of the forwarder's mass was replaced during its operational lifetime, $56 \%$ of mass for single-grip harvester and $50 \%$ of mass for two-grip harvester. About $6 \%$ of the machinery's life cycle energy consumption was due to activities connected with the production of the vehicles; raw material acquisition and intermediate processing, fabrication of individual components, assembly of the vehicles and associated transports.

McManus et al. (2004) analyzed the life cycle of mineral oil and BIO (rapeseed) oil used in mobile hydraulic systems (Table 6). The authors note that the use of BIO oil is a relatively new process and that it is difficult to obtain accurate input data. In most emissions occurring in the production of both types of oil, emissions of pollutants at production of BIO oil exceed those in production of mineral oil, except in greenhouse gas emissions. Authors further conclude that although it is not always better to use the BIO (negative impact on parts of the hydraulic system - seals and hoses), production of mineral oil is by itself volatile because mineral oil is a derivative of non-renewable resources.

Schwaiger and Zimmer (2001) collected data from 12 European countries (data from Croatia was included from the study of Beuk et al. 2007) participating in the COST Action E9 "LCA of Forestry and Forest Products" (Figures 4, 5, 6). The study is restricted to the forest operations "harvesting" and "extraction" due to the lack of available data for all other forest processes such as "scarification", "stand establishment", "tending and seeding", "clearing" or "use of pesticides", "forest road construction and maintenance", "delimbing", "debarking" etc. Quantity and quality of information available varied 
considerably. Data, such as felling, increment, forest area, etc., are available in all countries and performance data on forest operations were not often available (e.g. transport distances were assumed ...). In countries such as Austria, Finland, Switzerland and Sweden larger amounts of data were available at the national level. However, it should be noted that in none of the analyzed countries secondary forest products (in the lifecycle analysis) were not mentioned and no differences was made between the timber harvested in thinnings or in final fellings (clear cuts).

\begin{tabular}{|l|c|c|}
\hline \multirow{2}{*}{ Category } & \multicolumn{2}{c|}{ Total people emission equivalents } \\
\cline { 2 - 3 } & Mineral oil & BIO rapeseed oil \\
\hline Greenhouse gases & $2.73^{*} 10^{-4}$ & $2.30^{\star} 10^{-5}$ \\
\hline Ozone-depleting gases & $9.61^{*} 10^{-12}$ & $4.59^{*} 10^{-10}$ \\
\hline Acidification & $3.41^{*} 10^{-5}$ & $2.91^{*} 10^{-5}$ \\
\hline Eutrophication & $9.89^{*} 10^{-6}$ & $2.68^{\star} 10^{-5}$ \\
\hline Heavy metals & $9.23^{*} 10^{-6}$ & $6.90^{*} 10^{-6}$ \\
\hline Carcinogens & $1.49^{*} 10^{-10}$ & $5.99^{*} 10^{-9}$ \\
\hline Winter smog & $1.91^{*} 10^{-5}$ & $1.03^{*} 10^{-5}$ \\
\hline Summer smog & $8.96^{*} 10^{-10}$ & $2.67^{*} 10^{-5}$ \\
\hline Pesticides & 0 & $1.48^{*} 10^{-5}$ \\
\hline Energy & $3.73^{*} 10^{-5}$ & $3.89^{*} 10^{-5}$ \\
\hline Solid waste & 0 & 0 \\
\hline
\end{tabular}

Table 6. Normalized data for the production of $1 \mathrm{~kg}$ of mineral and rapeseed BIO oil
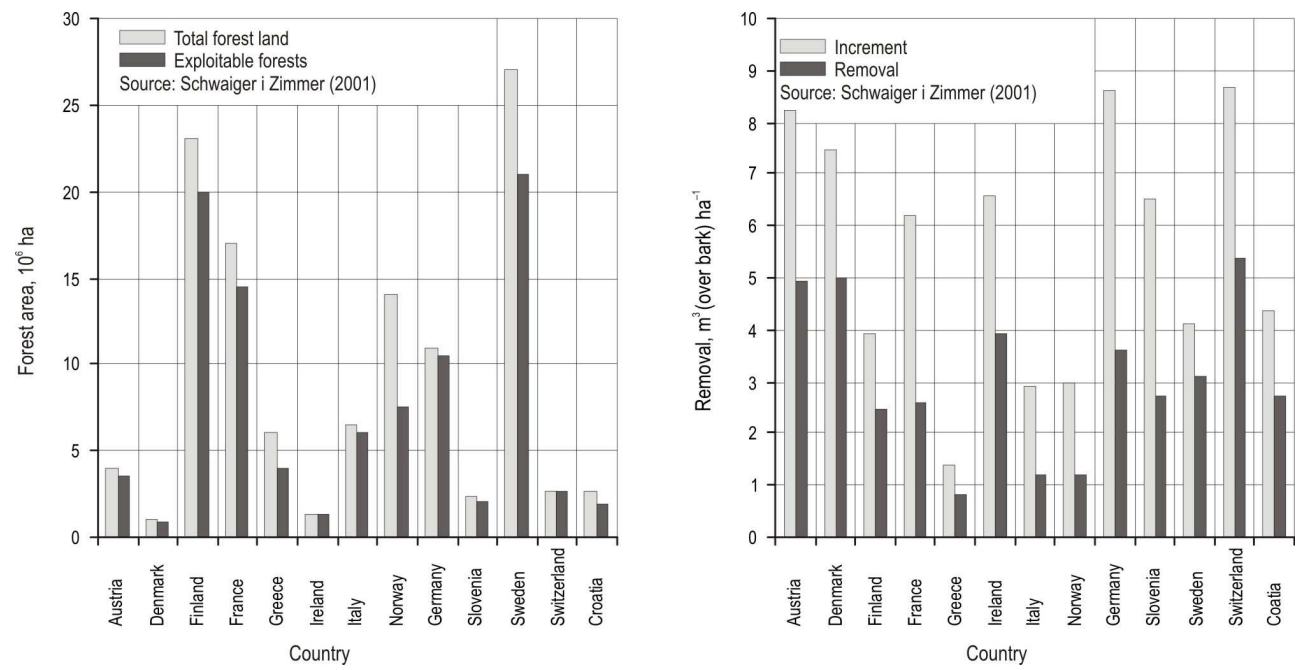

Fig. 4. Data of forest land, increment and removal

Authors claim that data availability depended on forest ownership (Table 7) because data from private and company forests were often incomplete. 


\begin{tabular}{|l|c|c|c|c|c|}
\hline \multirow{2}{*}{ State } & $\begin{array}{c}\text { State } \\
\text { forests }\end{array}$ & $\begin{array}{c}\text { Federal } \\
\text { forests }\end{array}$ & $\begin{array}{c}\text { Corporation } \\
\text { forests }\end{array}$ & $\begin{array}{c}\text { Private } \\
\text { forests }\end{array}$ & $\begin{array}{c}\text { Company } \\
\text { forests }\end{array}$ \\
\cline { 2 - 6 } & \multicolumn{5}{|c|}{$\%$} \\
\hline Austria & 17.0 & 3.5 & 9.8 & 69.7 & - \\
\hline Denmark & 40.0 & - & - & 54.3 & 7.8 \\
\hline Finland & 33.2 & - & 4.7 & 73.6 & - \\
\hline France & 10.2 & - & 16.2 & 40.0 & - \\
\hline Germany & 4.3 & 29.6 & 26.1 & - & - \\
\hline Greece & - & - & - & 35.0 & 65.0 \\
\hline Ireland & - & - & - & 59.9 & 5.1 \\
\hline Italy & 7.6 & - & 27.4 & 64.0 & - \\
\hline Norway & 7.0 & 2.0 & - & 49.2 & 2.4 \\
\hline Slovenia & 32.6 & - & - & 29.0 & 39.4 \\
\hline Sweden & 3.4 & - & 8.0 & 4.3 & - \\
\hline Switzerland & 5.0 & 1.0 & 62.0 & & 3.0 \\
\hline Croatia & 76.0 & 19.7 & - & & \\
\hline
\end{tabular}

Table 7. Distribution of forest ownership

In order to create standardized and representative data suitable for comparison, harvesting was divided to felling and timber transport (Figure 5). Timber transport was further divided to timber extraction and remote transport (Figure 6)
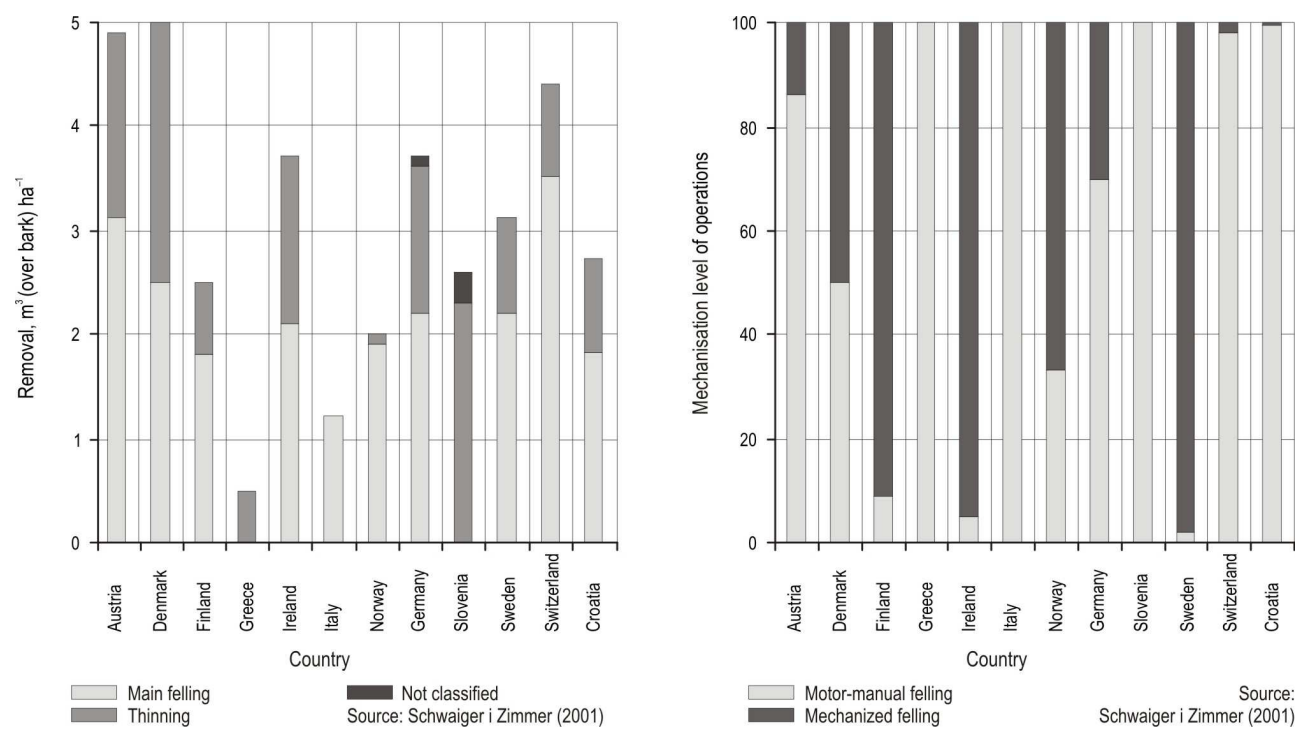

Fig. 5. Removal structure and mechanization level of felling and processing

Mechanization level of timber harvesting and processing in these countries should be compared with respect to the proportion of tree species in the growing stock, type of forest management, terrain (the influence of terrain slope, surface barriers and the load-bearing 
capacity of forest vehicles) and to the relationship between incomes gained in timber felling (Figure 4).
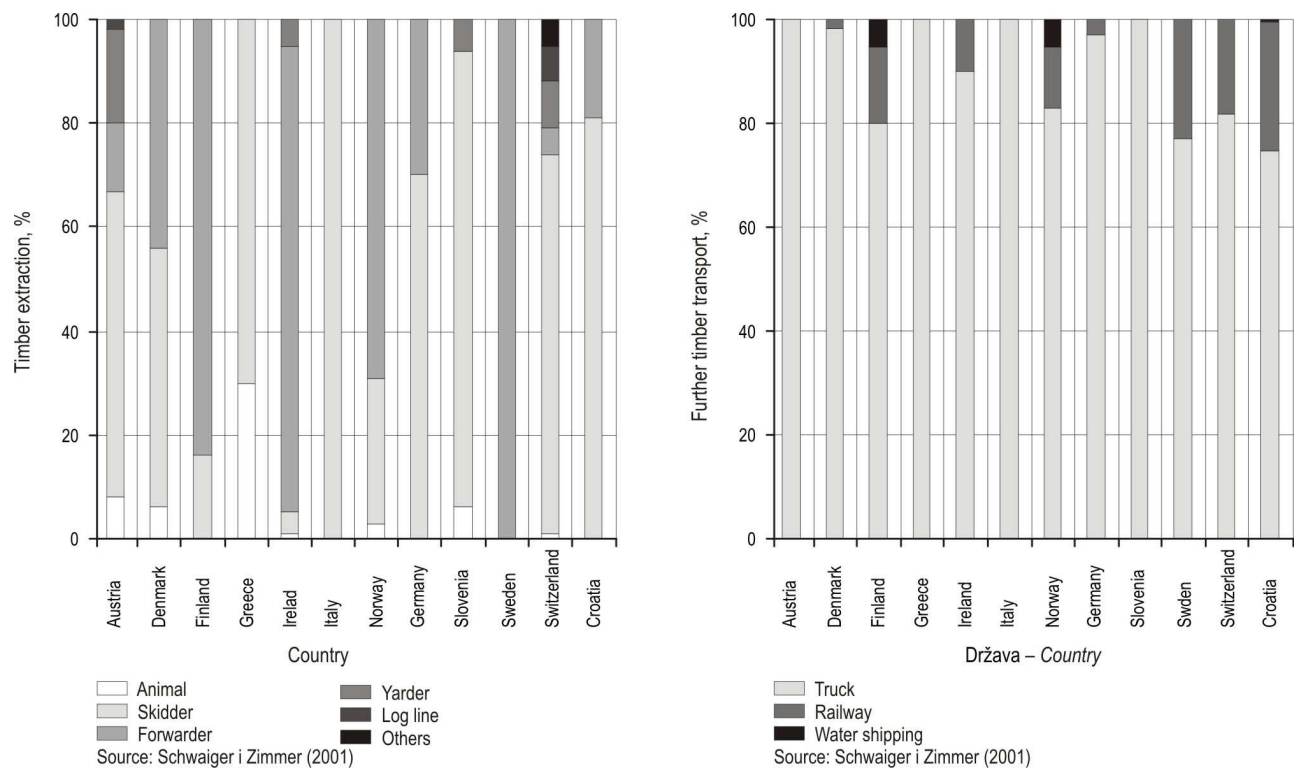

Fig. 6. Structure of timber extraction and further transport

On the choice of extraction vehicles used, the above-mentioned terrain factors and certainly the level of road openness was crucial which has led to significant performance differences in the primary timber transport between European countries (Figure 5).

Remote (secondary) timber transport for all European countries mainly relies on the transport of timber by trucks (> 75\%).

Shares of transport by rail and water in some European countries are related to the existence of a network of railroads and their affiliation with the international transport corridors, or the existence of navigable waterways.

In analyzing life cycle, except general information related to individual forestry (Figures 3, 4 and 5), the environmental assessment is required and the data on productivity, fuel consumption and the amount of discharged pollutants are an integral part of each harvesting systems (Table 8 ).

Transport of timber with trucks significantly affects the life cycle analysis, because fuel consumption and exhaust (GHG) emissions depend on the distance of transport and vehicle type. It should be noted that legal restrictions vary considerably within European countries (Table 9), and that the total number of axles affect considerably on the permissible weight of the vehicle and trailer. Fuel consumption per kilometre for trucks depends on the type and age of the vehicle, its total weight and the distance of timber transportation. However, due to lack of data on the structure of passed kilometres, depending on the type of road (public, 
forest roads), the greatest attention was on relative fuel consumption due to the volume of transported wood (Table 9).

\begin{tabular}{|c|c|c|c|c|c|c|c|}
\hline \multirow{3}{*}{$\begin{array}{l}\text { Means of work } \\
\text { (producer) }\end{array}$} & \multirow{3}{*}{ Reference } & \multirow{3}{*}{\begin{tabular}{|c|} 
Productivity \\
$\mathrm{m}^{3} / \mathrm{h}$
\end{tabular}} & \multirow{2}{*}{\multicolumn{2}{|c|}{$\begin{array}{c}\text { Fuel } \\
\text { consumption }\end{array}$}} & \multicolumn{3}{|c|}{$\begin{array}{l}\text { Exhaust } \\
\text { gasses }\end{array}$} \\
\hline & & & & & $\mathrm{CO}_{2}$ & $\mathrm{~N}_{2} \mathrm{O}$ & $\mathrm{CH}_{4}$ \\
\hline & & & $\mathrm{l} / \mathrm{h}$ & $\mathrm{kg} / \mathrm{m}^{3}$ & \multicolumn{3}{|c|}{$\mathrm{g} / \mathrm{kg}$ fuel } \\
\hline \multicolumn{8}{|c|}{ Felling and processing } \\
\hline Chainsaw (Stihl 026) & Fedrau (2000) & 4.00 & 1.50 & 0.28 & 3150 & 0.02 & 6.91 \\
\hline Chainsaw (Stihl 036) & Fedrau (2000) & 8.00 & 2.40 & 0.23 & 3150 & 0.02 & 6.91 \\
\hline Chainsaw (Stihl 026/036) & Fedrau (2000) & 6.00 & 2.00 & 0.24 & 3150 & 0.02 & 6.91 \\
\hline $\begin{array}{l}\text { Harvester (Timberjack } \\
1270)\end{array}$ & Knechtle (1997) & 13.00 & 11.30 & 0.77 & 3455 & 2.20 & 5.23 \\
\hline \multicolumn{8}{|c|}{ Timber transport } \\
\hline Animal (horse) & FPP(1991) & 1.50 & - & - & - & - & - \\
\hline Skidder (Mahler Unifant) & Fedrau (2000) & 7.00 & 6.00 & 0.64 & 3455 & 2.20 & 5.23 \\
\hline $\begin{array}{l}\text { Forwarder (Timberjack } \\
810 \mathrm{~B})\end{array}$ & Knechtle (1997) & 17.00 & 9.80 & 0.43 & 3455 & 2.20 & 5.23 \\
\hline Yarder (Sincrofalke) & Winkler (1997) & 6.00 & 7.20 & 0.90 & 3455 & 2.20 & 5.23 \\
\hline Log line (Leykam) & $\begin{array}{l}\text { Trzesniowski } \\
(1989)\end{array}$ & 1.50 & - & - & - & - & - \\
\hline Truck (MAN) & Frischnecht (1995) & - & 4.00 & & 3180 & 0.10 & 0.20 \\
\hline
\end{tabular}

Source: Schwaiger i Zimmer (2001)

Table 8. Productivity, fuel consumption and amount of exhaust gasses in harvesting operations

\begin{tabular}{|l|c|c|}
\hline \multirow{1}{*}{ Country } & $\begin{array}{c}\text { Fuel } \\
\text { consumption }\end{array}$ & $\begin{array}{c}\text { Allowed } \\
\text { weight }\end{array}$ \\
\cline { 2 - 3 } & $\mathrm{kg} / \mathrm{m}^{3 *} 100 \mathrm{~km}$ & $\mathrm{t}$ \\
\hline Austria & 1.47 & 38 \\
\hline Denmark & 1.28 & 48 \\
\hline Finland & 1.16 & 56 \\
\hline Germany & 1.42 & 40 \\
\hline Greece & 1.47 & 24 \\
\hline Ireland & 1.43 & 40 \\
\hline Italy & 1.42 & 44 \\
\hline Norway & 1.28 & 50 \\
\hline Slovenia & 1.42 & 40 \\
\hline Sweden & 1.14 & 60 \\
\hline Switzerland & 1.42 & 40 \\
\hline
\end{tabular}

Table 9. Fuel consumption and total allowed weight of trucks

The total amount of pollutants disposed into the environment during forest operations is directly linked with the consumption of fossil fuels. Table 10 shows the estimated fuel consumption in European countries in different harvesting operations. 


\begin{tabular}{|l|c|c|c|c|}
\hline \multirow{2}{*}{ Country } & Felling and processing & Timber extraction & Further transport & Total \\
\cline { 2 - 5 } & \multicolumn{3}{|c|}{$\mathrm{kg} \mathrm{fuel} / \mathrm{m}^{3}$} \\
\hline Austria & 0.31 & 0.59 & 3.68 & 4.60 \\
\hline Denmark & 0.51 & 0.46 & 1.28 & 2.30 \\
\hline Finland & 0.73 & 0.36 & 2.08 & 3.20 \\
\hline Germany & 0.40 & 0.58 & 5.89 & 2.40 \\
\hline Greece & 0.28 & 0.45 & 1.98 & 3.60 \\
\hline Ireland & 0.75 & 0.48 & 0.86 & 1.70 \\
\hline Italy & 0.24 & 0.64 & 1.41 & 2.50 \\
\hline Norway & 0.60 & 0.47 & 0.99 & 1.90 \\
\hline Slovenia & 0.24 & 0.62 & 2.08 & 3.30 \\
\hline Sweden & 0.77 & 0.43 & 1.22 & 2.00 \\
\hline Switzerland & 0.25 & 0.58 & &
\end{tabular}

Table 10. Estimated fossil fuel input for harvesting operations

Authors conclude that the forest data availability in European countries differs significantly. While data of forest land use (ha), distribution of tree species (\%), growing stock, increment and harvested volume $\left(\mathrm{m}^{3}\right)$ are available in all countries, specific data and information on different forest operation are rather small.

Heinimann et al. (2006) state that since the introduction of ISO 14030 environmental impact awareness became more present, but there is still nevertheless a small number of prepared and/or published studies with forestry topics. The same author explores the environmental benefits of certain harvesting operations with respect to energy consumption, carbon dioxide emission, as well as carbon sequestration. Determines the energy consumption in the range of 0.12 to $0.62 \mathrm{MJ} / \mathrm{kg}$, which is only $0.5-3.7 \%$ of energy gained form forest biomass production. The $\mathrm{CO}_{2}$ emissions amounted to 0.005 to $0.032 \mathrm{~kg} / \mathrm{kg}$ of forest biomass, for which from 0.005 to $0.018 \mathrm{~kg}$ of forest biomass must be produced which would lead to carbon sequestration in trees. Although it was previously thought that felling and processing of wood with a chainsaw (motor-manual cutting) is more environmentally friendly, it was proved by the author that completely mechanized felling and processing (harvester-forwarder system) of short wood has the same impact on the environment (Figure 7).

Data on the life cycle of machines used in forestry can also be obtained from some manufacturers. Timberjack (John Deere Group member) in its "environmental label" provides information about the environmental impact of harvester Timberjack 770 and Timberjack 1410 forwarders throughout their life cycle (Figure 8), which is divided into these five periods:

- Extraction of raw materials - the impact on the environment during the manufacture of steel, cast iron, rubber ...

- Production of the vehicle - the impact on the environment in the development and preparation of the vehicle (determined by ISO 14001);

- Use of vehicles - dumping pollutants into the environment due to the consumption of fuels and lubricants;

- Vehicle maintenance and repairs - the environmental impact of disposal and recycling of old oil, tires and other vehicle parts; 
- Use of materials at the end of the life cycle - materials recovery and recycling with reuse of parts and storage of non-recyclable materials.
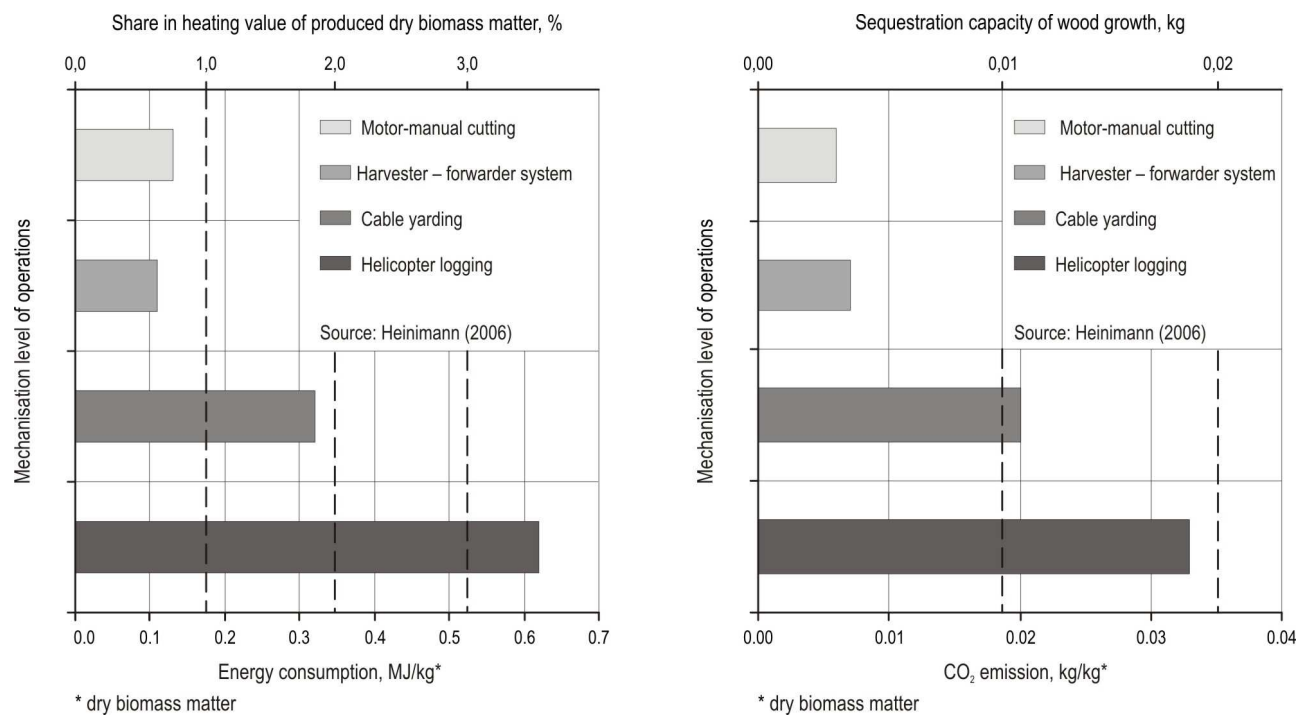

Fig. 7. Environmental suitability of some harvesting technologies

The greatest impact on the environment throughout the life cycle of both vehicles had a period of vehicle use (Figure 8). Period of vehicle use should be perceived by the two parameters known in the cost calculations of machine work: 1) normal use of the vehicle corresponds to the number of operating hours during which the operating cost per hour does not increase due to increased maintenance costs (for the harvester and forwarder it is usually 10000 operating hours), 2) during the obsolescence of the vehicle which corresponds to the greatest time period in years when the use of the vehicle is still economical, and after which comes technological obsolescence (corrosion, fatigue) and reduction of operational safety (for the harvester and forwarder it is usually 10 years).

In the period of vehicle use, the biggest impact on the environment is made due to consumption of fossil fuels (Table 11). The most important pollutants are vehicle exhaust gasses, carbon dioxide (as the most important greenhouse gas that affects global warming), nitrogen oxides (as one of the causes of acid rain), and as well as sulphur oxides (cause respiratory diseases).

The environmental benefit of each product is presented with the possibility for recycling or reuse of materials at the end of its life cycle. Recycling must be primarily technologically feasible, and economically viable. The rate of vehicle recycling at the end of its period of use is determined by the ratio of the mass of materials that can be recycled and the total mass of the vehicle. According to EU Directive 2000/53/EC, the rate of recovery at the end of the period of use of vehicles must be at least $80 \%$ (i.e. $85 \%$ when reusable parts of the machine are taken into account). Till the year 2015 the prescribed recycling rate will be $85 \%$ (i.e. $95 \%$ when reusable parts of the machine are taken into account). 

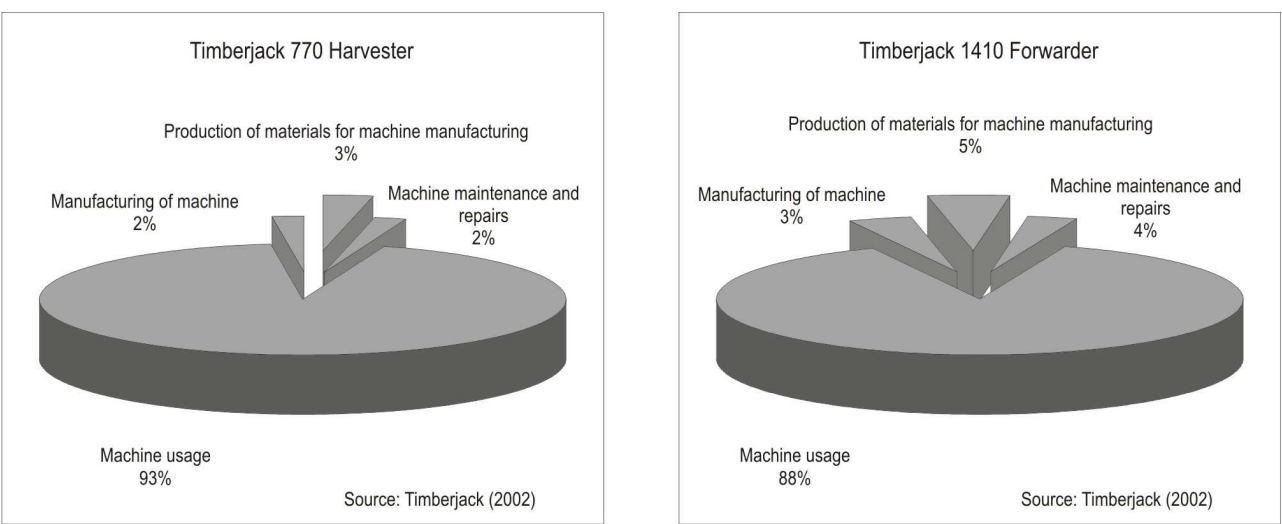

Fig. 8. Environmental impact throughout different life cycle phases of harvester and forwarder

\begin{tabular}{|c|c|c|c|c|c|c|c|c|}
\hline \multirow{3}{*}{$\begin{array}{c}\text { Vehicle } \\
\text { type }\end{array}$} & \multicolumn{8}{|c|}{ Gaseous and particulate emission } \\
\cline { 2 - 9 } & Total & $\begin{array}{c}\text { During } \\
\text { usage }\end{array}$ & Total & $\begin{array}{c}\text { During } \\
\text { usage }\end{array}$ & Total & $\begin{array}{c}\text { During } \\
\text { usage }\end{array}$ & Total & $\begin{array}{c}\text { During } \\
\text { usage }\end{array}$ \\
\cline { 2 - 10 } & \multicolumn{8}{|c|}{$\mathrm{kg}$} \\
\hline Harvester & 499000 & 451400 & 5428 & 5293 & 624 & 523 & 284 & 256 \\
\hline Forwarder & 509100 & 451400 & 4356 & 4206 & 713 & 523 & 232 & 209 \\
\hline
\end{tabular}

Source: Timberjack (2002)

Table 11. Pollutions during harvester and forwarder life cycle

At the end of the period of use, the harvester waste (un-recyclable materials) is less than $8 \%$ of the total mass, and forwarder waste is even smaller, only $4 \%$ of the total vehicle's mass (Figure 9).

The VTT Technical Research Centre of Finland applied the LCA method in a study to determine the most significant environmental impacts of the Timberjack 1490D slash bundler. In the LCA study of the slash bundler, environmental impact is divided into five phases:

1. Production of materials,

2. Manufacturing of the machine,

3. Usage,

4. Maintenance and repairs,

5. Post-use disposal.

The total emissions of carbon dioxide is $727001 \mathrm{~kg}$ where $88 \%$ of the total carbon dioxide emissions occur during entire life cycle of the slash bundler. Nitrogen oxide emissions amount to $4881 \mathrm{~kg}$ during the slash bundler's life cycle (96\% during usage phase). $1402 \mathrm{~kg}$ of sulphur oxides are generated (84\% during usage phase) and $246 \mathrm{~kg}$ of particulate emissions are generated during the usage phase. Slash bundler is built on forwarder chassis, to which is attached the bundler component and the automation that drives its usage, so the recyclability rate is the same as for forwarders (Fig.10).

Økstad (1995) states that common experiences for paper and pulp industry in Norway with LCA projects in gathering data, from the production process and the raw materials, is much 

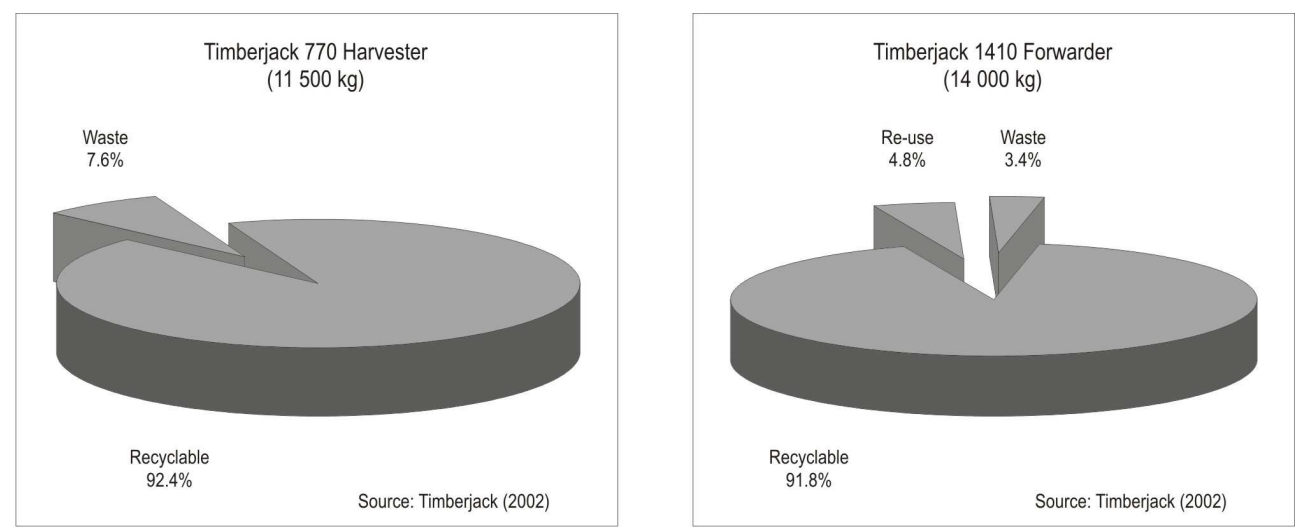

Fig. 9. Harvester and forwarder recyclability rate
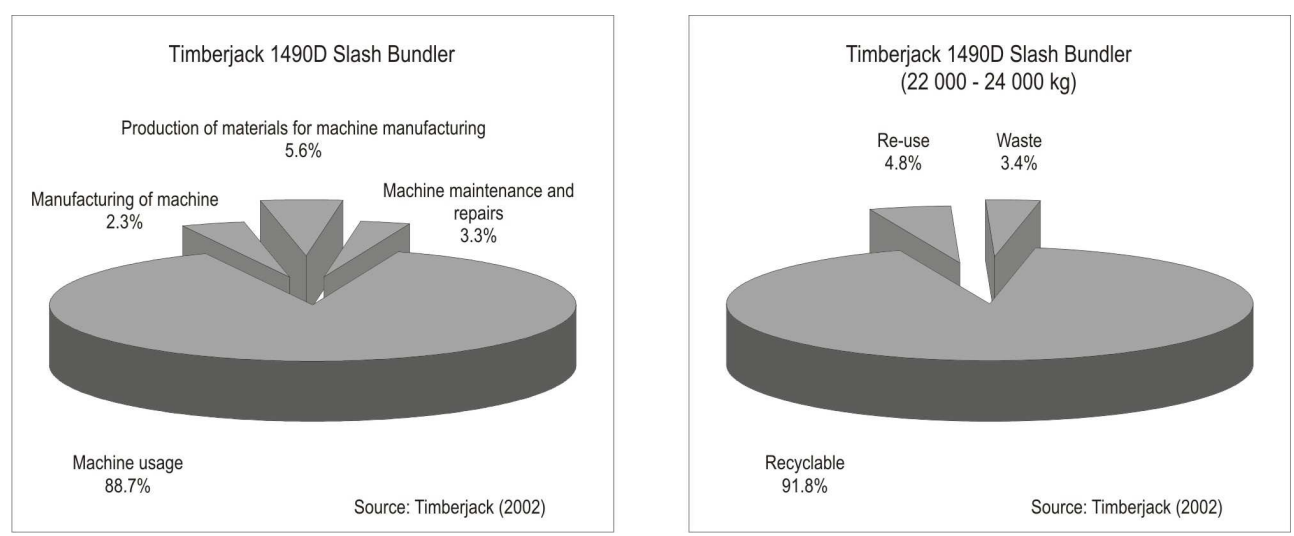

Fig. 10. Environmental impact throughout different life cycle phases of a slash bundler and its recyclability rate

larger task than assumed. Even if there is a good knowledge of the total emissions and the energy demand of the factory, the processes are often integrated and there are problems allocating different emissions to the products. In addition to the internal problems of finding the correct data from the manufacturing processes there are problems to procure data from the processing of raw materials (forest products and chemicals). Author further claims that some pulp and paper companies have established their own expertise in the field of LCA on the corporate level and have their own LCA strategy:

- $\quad$ LCA is seen as a useful tool in the development of the new products;

- $\quad$ LCA may be used in the process to select the most environmentally friendly product. It is emphasised that it may be difficult to get a just result from such comparisons because different system boundaries in the assessment will lead to different answers;

- $\quad$ LCA may be used as a tool to identify the points in the production process which gives the highest environmental impacts and where the potential improvement is the highest; 
- Having carried out LCA of their own products gives the industry much better "cards on hand" in the communication with local and national environmental authorities.

Some companies have taken the challenge and initiated their own work to collect data and carry out LCA of their activities and products, while others have a more reluctant attitude towards the method and have the opinion that the method is not fully developed to be used as a tool for industry. Author concludes that LCA is a useful tool in the development of new products and it may be used in the process of selecting the most environmentally friendly product or for highlighting points in the production process which give the highest environmental impact. In some cases LCA will be required in the licensing process of discharge permits.

\section{Conclusion}

Life cycle assessment is a very complex tool in the process of assessing the environmental impact of a product. To be successfully developed, high quality data sources are required that will contain all the inputs and outputs of different materials used, energy consumption and the amount of pollutants and emissions produced during:

1. Extraction of raw materials,

2. Product production,

3. Time of product usage,

4. Possible recycling and re-use,

5. Final disposal of waste.

For forestry, the life cycle assessment is particularly difficult due to the long production process of raw materials, primarily wood (length of rotation period), and because of the high spatial and temporal impact forests have on the environment. As the life cycle assessment is a static and not a dynamic tool of environmental impact, many experts believe that the spatial and temporal aspects should be excluded from the assessment itself. However, the life cycle assessment related to forestry and its products makes such exclusion impossible. Forests not only have an important social impact, but they store large amounts of carbon (carbon sequestration), protect soil and water resources, ensure biodiversity, produce oxygen, etc., thus affecting the global climate. These are beneficial functions of forests that can not and should not be ignored when dealing with life cycle assessment in forestry. On the other hand, the question of how to include all forest management activities (from silviculture to forest protection and harvesting) could be involved in the life cycle assessment of forest products.

Life cycle assessment is a good tool for determining the effects of each product (and manufacturing processes in which the product is being produced) on the environment, especially today when there is more and more awareness of environmentally friendly technologies, renewable energy and eco-efficiency. The greatest use of life cycle assessment tool in forestry, from the aspect of timber harvesting, is in comparing different harvesting systems for selecting environmentally friendly versions.

Due to the lack of quality data sources, and conversion between a static to a dynamic character of the life cycle assessment, requires further research and improvement of this otherwise useful, but very complex tool in assessing the environmental acceptability of products and production processes. 


\section{References}

Anon., (1997). Memorandum of Understanding for the implementation of a European Concerted Research, COST Action E9, Life cycle assessment of forestry and forest products. Technical annex, April 11, 1997, Bruxelles, Belgium.

Athanassiadis, D., (2000). Resource consumption and emissions induced by logging emissions induced by logging machinery in life cycle perspective. Dissertation, ISBN 9157658773, Umeå, Swedish University of Agricultural Sciences, 88 pages.

Berg, S., (1998). An inventory of forest operations for LCA of forest products. International Conference of life cycle assessment in agriculture, Agro-Industry and Forestry, 3-4 December 1998, Brussels, Belgium.

Berg, S. and Karjalainene, T. (2000). Comparision of emissions from forest operations in Finland and Sweden. Presentation at COST Action E9, Mid-term Seminar in Espooo/Finland, Dipoli 27-29 March 2000.

Beuk, D., Ž. Tomašić, D. Horvat, (2007). Status and development of forest harvesting mechanisation in Croatian state forestry. Croatian journal of forest engineering, 28(1): 63-82.

Cowell, S. J., \& Clift, R. (2000). A Methodology for Assessing Soil Quantity and Quality in LCA. Journal of Cleaner Production, Vol. 8, 321-3, ISSN: 0959-6526.

De Feyter, S., (1995). Handling of the Carbon Balance of Forest in LCA. Proceedings of the International Workshop: Life-Cycle Analysis - A Challenge for Forestry and Forest Industry, May 3-5, 1995, Hamburg, Germany, pg. 37-43.

Frühwald, A., (1995). LCA - A Challenge for Forestry and Forest Products Industry. Proceedings of the International Workshop: Life-Cycle Analysis - A Challenge for Forestry and Forest Industry, May 3-5, 1995, ISBN:952-9844-16-6, Hamburg, Germany, pg. 9-14.

Guineé, J., L. van Oers, A. de Koning, W. Tamis, (2006). Life Cycle Approaches for Conservation Agriculture, Part I: A definition study for data analysis. CML report 171, June 2006, Universiteit Leiden, ISBN-10: 90-5191-148-3, Leiden, Netherlands, pg. 1-67.

Grasser, C. (1994). Ökoinventare für Energiesysteme. Grunlagen für den ökologische Vergleich van Energiesystemen und der Einbezug van Energiesystemen in ökobilanzen für die Schweiz. Bundesamt für Energiewirtschaft.

Häkkinen, T. and Mäkelä, K. (1996). Environemtal adaption of concrete. Environmental impact of concrete and asphalt pavements. VTT Research Notes 1752. ISBN 951-384507-4, Espoo, Finland, 61 pages.

Heinimann, H. R., A. Wollenmann, R. Knechtle, (2006). Life Cycle Approaches for Conservation Agriculture, Part I: A definition study for data analysis. CML report 171, June 2006, Universiteit Leiden, ISBN-10: 90-5191-148-3, Leiden, Netherlands, poster presentation.

Jungmeier, G., (2003). System Analysis of Forestry, Forest products and Recovered Wood. International Conference »Efficient Use of Biomass for Greenhouse Gas Mitigation«. COST Action E9 and E31, PPT, September 30 - October 1, Österund, Sweden.

Karjalainene, T., T. Apnesth, P. Esser, L. Finér, G. Jungmeier, B. Košir, K. E. Kvist, J. M. Roda, H. Schwaiger, S. Berg, B. Zimmer, J. Welling, (2001). Identification of Problems using Case Studies. Energy, Carbon and Other Material Flows in the Life Cycle Assessment of Forestry and Forest Products. Achievements of the working group 1 of the COST action E9, European Forest Institute, Discussion paper 10, ISBN: $952-$ 9844-92-1, Joensuu, Finland, pg. 9-21. 
Lox, F. (1994). Milieubalans van vouwkarton. Vrije Universiteit Brussels, in opracht van Pro Carton België, draft, april 1994.

Mcmanus, M. C., G. Hammond, C. R. Burrows, (2004). Life-cycle Assessment of Mineral and Rapeseed Oil in Mobile Hydraulics Systems. Journal of Industrial Ecology, 7(3-4): 163-177, ISSN: 1530-9290.

Mroueh, U. M., P. Eskola, J. Laine-Ylijoki, K. Wellman, E. M. M. Juvankoski, A. Ruotoistenmäki, (2000). Life Cycle Assessment of Road Construction. Finnra report, 17/2000, ISBN 951-726-633-2, Helsinki, Finland, 59 pages.

Nabuurus, G., J. and Mohren G., M., J. (1993). Carbon fixation through forestation activities. A study of the carbon sequestration potential of selected forest types. Institute for Forestry and Nature Research (IBN-DLO), Arnhem/Wageningen.

Økstad, E., (1995). Experience with LCA in the pulp, paper and packaging industry in Norway. Proceedings of the International Workshop: Life-Cycle Analysis - A Challenge for Forestry and Forest Industry, May 3-5, 1995, Hamburg, Germany, pg. 141-149.

Ranta, J., Wahlström, M., Rouhomäki, J., Häkkinen, T. and Lindroos, P. (1987). Desulphurisation products of coal combustion plants. VTT Research Notes 741. Espoo, 140 pages.

Schwaiger, H., B. Zimmer, (2001). A comparison of Fuel Consumption and Greenhouse Gas Emissions from Forest Operations in Europe. Energy, Carbon and Other Material Flows in the Life Cycle Assessment of Forestry and Forest Products. Achievements of the working group 1 of the COST action E9, European Forest Institute, Discussion paper 10, : 952-9844-92-1, Joensuu, Finland, pg. 33-53.

Timberjack, (2002): Green forest machines for sustainable development - Environmental Declaration. Timberjack - A John Deere Company, Tampere, Finland, 12 pages.

Thoroe, C., J. Schweinle, (1995). Life Cycle Analysis in Forestry. Proceedings of the International Workshop: Life-Cycle Analysis - A Challenge for Forestry and Forest Industry, May 3-5, 1995, ISBN: 952-9844-16-6, Hamburg, Germany, pg. 15-24.

Virtanen, Y. and Nilsson, S. (1993). Environmental impacts of waste paper recycling. International Institute for Applied Systems Analysis, Earthscan Publications Ltd, ISBN 1853831603, London, UK, 166 pages.

Wollenmann, R., (2006). Balancing Carbon Emission and Sequestration Fluxes of Forest Land Based on LCI - approach. ). Life Cycle Approaches for Conservation Agriculture, Part I: A definition study for data analysis. CML report 171, June 2006, Universiteit Leiden, ISBN-10: 90-5191-148-3, Leiden, Netherlands, poster presentation.

www.iso.org

www.admin.cam.ac.uk 


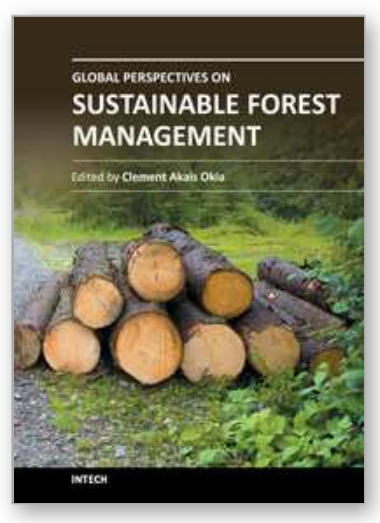

\author{
Global Perspectives on Sustainable Forest Management \\ Edited by Dr. Dr. Clement A. Okia
}

ISBN 978-953-51-0569-5

Hard cover, 300 pages

Publisher InTech

Published online 25, April, 2012

Published in print edition April, 2012

This book is dedicated to global perspectives on sustainable forest management. It focuses on a need to move away from purely protective management of forests to innovative approaches for multiple use and management of forest resources. The book is divided into two sections; the first section, with thirteen chapters deals with the forest management aspects while the second section, with five chapters is dedicated to forest utilization. This book will fill the existing gaps in the knowledge about emerging perspectives on sustainable forest management. It will be an interesting and helpful resource to managers, specialists and students in the field of forestry and natural resources management.

\title{
How to reference
}

In order to correctly reference this scholarly work, feel free to copy and paste the following:

Andreja Bosner, Tomislav Poršinsky and Igor Stankić (2012). Forestry and Life Cycle Assessment, Global Perspectives on Sustainable Forest Management, Dr. Dr. Clement A. Okia (Ed.), ISBN: 978-953-51-0569-5, InTech, Available from: http://www.intechopen.com/books/global-perspectives-on-sustainable-forestmanagement/forestry-and-life-cycle-assessment

\section{INTECH}

open science | open minds

\section{InTech Europe}

University Campus STeP Ri Slavka Krautzeka 83/A 51000 Rijeka, Croatia Phone: +385 (51) 770447

Fax: +385 (51) 686166 www.intechopen.com

\section{InTech China}

Unit 405, Office Block, Hotel Equatorial Shanghai No.65, Yan An Road (West), Shanghai, 200040, China 中国上海市延安西路65号上海国际贵都大饭店办公楼 405 单元 Phone: +86-21-62489820

Fax: +86-21-62489821 
(C) 2012 The Author(s). Licensee IntechOpen. This is an open access article distributed under the terms of the Creative Commons Attribution 3.0 License, which permits unrestricted use, distribution, and reproduction in any medium, provided the original work is properly cited. 